\title{
The Heuristic Method applied to Design for Sustainability in Urban
}

\section{Agriculture}

O Método Heurístico aplicado ao Design para Sustentabilidade na Agricultura Urbana

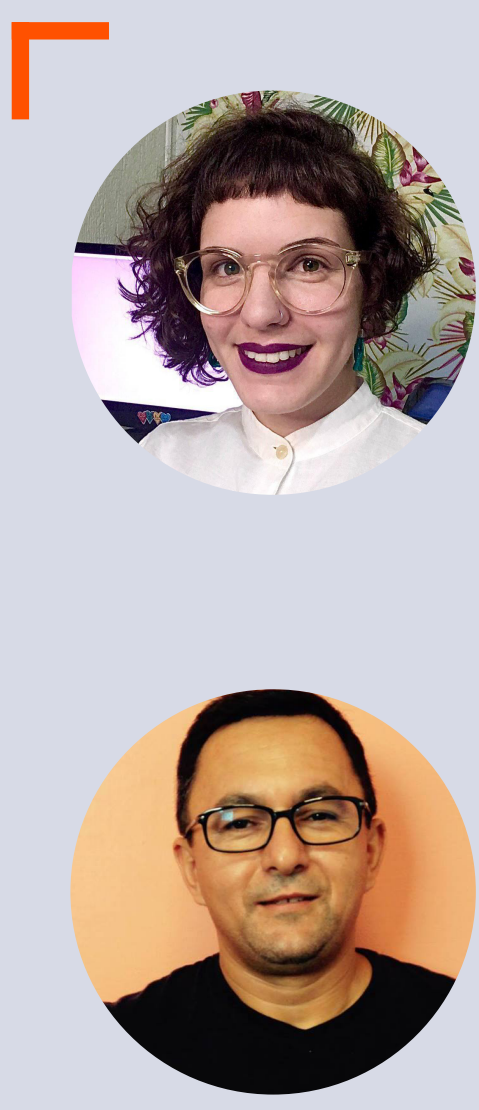

\section{Mariana Schmitz Gonçalves}

Master of Science in Design from the Federal University of Paraná

Design Department at UNINTER International University Center

tz.mariana@gmail.com

\section{Aguinaldo dos Santos}

PhD in Production Management from Salford University Postgraduate Program in Design at the Federal University of Paraná asantos@ufpr.br 


\section{ABSTRACT}

This article presents heuristics that allow for the expansion of social cohesion in urban agriculture initiatives. For this, two ex-post-facto case studies were carried out, in the Netherlands and Switzerland. Another objective of the research is to suggest the use of these heuristics in Service Design and Design for Social Innovation projects. The Heuristic Method is presented with the grounded theory approach and the steps to identify the heuristics. The contributions of this article are in the detailing of the Heuristic method and in the proposition of meta-actions to inspire Design actions based on the ten identified heuristics. These can be used by designers working with social innovations in urban agriculture.

\section{KEYWORDS}

Design for Sustainability; Heuristics; Urban Agriculture.

\section{RESUMO}

Este artigo apresenta heurísticas que permitam ampliar a coesão social em iniciativas de agricultura urbana. Para isso, fez-se dois estudos de caso ex-post-facto, na Holanda e na Suíça. Outro objetivo da pesquisa é sugerir a utilização destas heurísticas em projetos de Design de Serviço e Design para a Inovação Social. Apresenta-se o Método Heurístico com a abordagem de grounded theory e as etapas para identificação das heurísticas. As contribuições deste artigo estão no detalhamento do método Heurístico e na proposição de meta-ações para inspirar ações de Design baseadas nas dez heurísticas identificadas. Estas podem ser usadas por designers trabalhando com inovações sociais de agricultura urbana.

\section{PALAVRAS-CHAVE}

Design para a Sustentabilidade; Heurísticas; Agricultura Urbana. 


\section{INTRODUCTION}

This article presents the method and part of the results of a master's thesis that proposed meta-actions to assist designers working with Urban Agriculture (UA) initiatives, with a focus on increasing social cohesion in the community. These meta-actions for Design for Social Innovation and Service Design were derived from ten heuristics ${ }^{1}$ identified from two UA expost-facto case studies. It was given special attention to the Heuristic method with a grounded theory approach to illustrate how this research strategy can investigate issues of social interaction. In figure 1 it is possible to see the correlation between the themes covered in this research:

Figure 1 - Overview of the themes

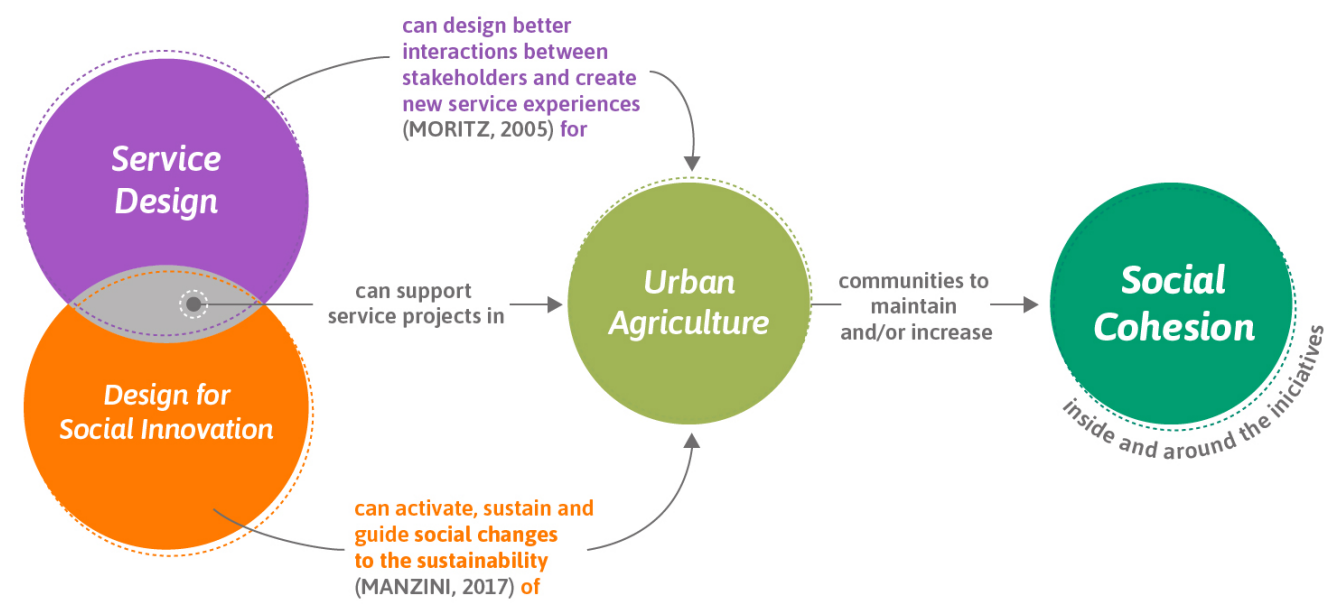

Source: Adapted from Moritz (2005) and Manzini (2017)

Social cohesion can be understood as the level of social interaction and the sense of union for a common purpose in a society (KARUPPANNAN \& SIVAM, 2011). Some fundamental aspects for greater social cohesion are communitarian values and a shared notion of morality. A strong sense of belonging to the place and a high level of interaction between the members of a group would then constitute a cohesive community (CHAVES et al., 2019). The contribution of Design to social cohesion is a

1 - Heuristic: From the Greek word "heuriskein", which means "to discover". It refers to aspects common to a type of practice, which can be seen as guidelines or good practices. They are standards directly backed by empirical data, identified in the field and validated by multiple data sources (SANTOS, et al., 2018). 
complex matter. Current collective and relational issues need a Design perspective that goes beyond tangible isolated products to address people's needs - both individual and those presented by groups. It is necessary to shift to design and offer intangible experiences, with services that promote systemic solutions not only for people, but for the environment and the economy (CIPOLLA et al., 2016).

Even though social cohesion has different dimensions, such as regional, national and international with a wide range of possibilities for the designer, it is at the local level that this professional has usually made more contributions. In fact, on the microeconomic scale, the designer can stand out as an agent of transversal articulation between different areas of knowledge, bringing together the various relevant factors in the transformation of habits and behaviors towards more sustainable standards. It is in this local and microeconomic dimension that UA initiatives are found.

For the field study of this research, "Urban Agriculture" is the activity of producing fruits, vegetables, herbs and even animals for food or other purposes in the cities. The most relevant quality of this way of farming, which differs from rural agriculture, is that urban agriculture is deeply integrated into the social, economic and ecological ecosystem of cities. City dwellers are employed as collaborators, there is a direct relationship with local consumers and some influence on urban planning and policies (MOUGEOT, 2000; VEENHUIZEN, 2006; RUAF, 2015). UA practices include everything from fully commercial cultivation, community initiatives between the neighborhood, to domestic production for own consumption. However, as this research has interest in improving social cohesion, domestic production was not included.

In its plurality, UA creates new ways for the people involved to interact socially. It brings with it a way of occupying and conceiving the urban space, motivating other demands and reverberating political-ideological symbologies (TRACEY, 2007; REYNOLDS, 2009; NAGIB, 2016). These factors point to the role of UA in maintaining and improving social cohesion. According to Moraes (2005), how cities present themselves collaborate in shaping the social behavior of their citizens. Thus, the tacit knowledge arising from the practice of UA causes and suffers influences on the configuration of the city at the same time. The techniques, behaviors of the people involved and the symbolic objectives of each initiative are adapted, 
creating their own know-how (FENIMAN, 2014). This tacit knowledge was explored in order to answer the research question: "How to increase social cohesion through Design via social innovations aimed at urban agriculture?".

\section{METHODOLOGICAL PROCEDURES}

The development strategy of this research can be described in two main phases: (i) combination of Systematic Review with Literature Review; (ii) Identification of heuristics resulting from the analysis of urban agriculture cases documented online through a grounded theory approach $^{2}$. Stages 1 (Collection) and 2 (Codification) correspond to the individual analysis of each case. From stage 3 (Cross Analysis), the heuristics of both cases are worked on simultaneously, as shown in figure 2:

Figure 2 - Field Research Strategy Overview

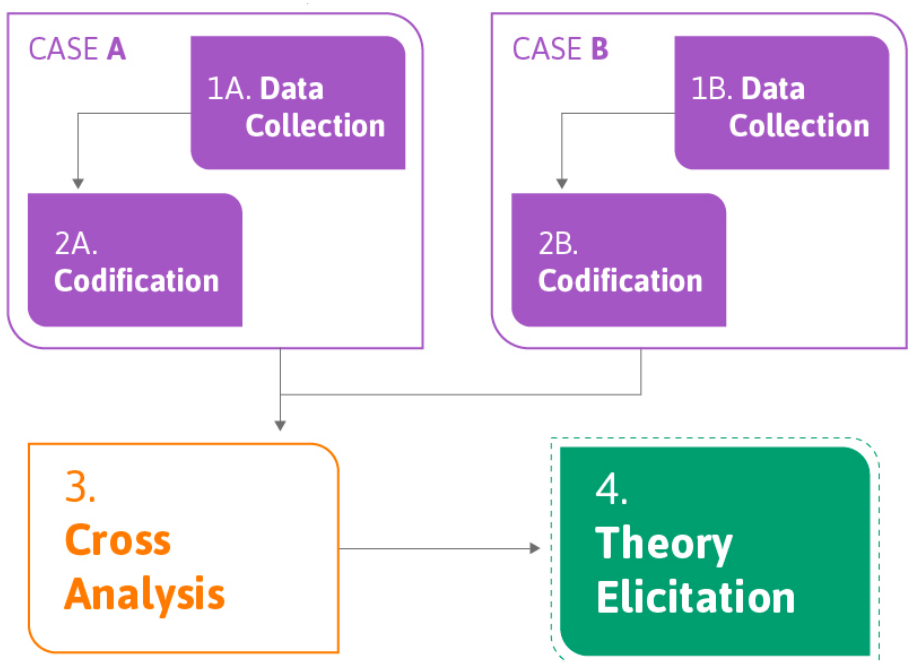

Source: Adapted from Lehmann (2001)

The unit of analysis in this research is social cohesion, which serves as a parameter for the identification of heuristics. This is assessed based on the

2 - The grounded theory approach is the continuous process of collecting evidence and abstraction of its meaning to build a theory backed by the saturation of the results obtained (SANTOS et al., 2018). The collected data is systematically classified and encoded for analysis, and the interpretation of this codification generates theoretical constructs about the studied context(CHARMAZ, 2009). 
proximity and intensity of social interactions, the sense of belonging of individuals and the union for a common purpose in an initiative (KARUPPANNAN \& SIVAM, 2011). The next figure (3) shows the protocol for data collection in detail:

Figure 3 - Protocol for data collection in detail

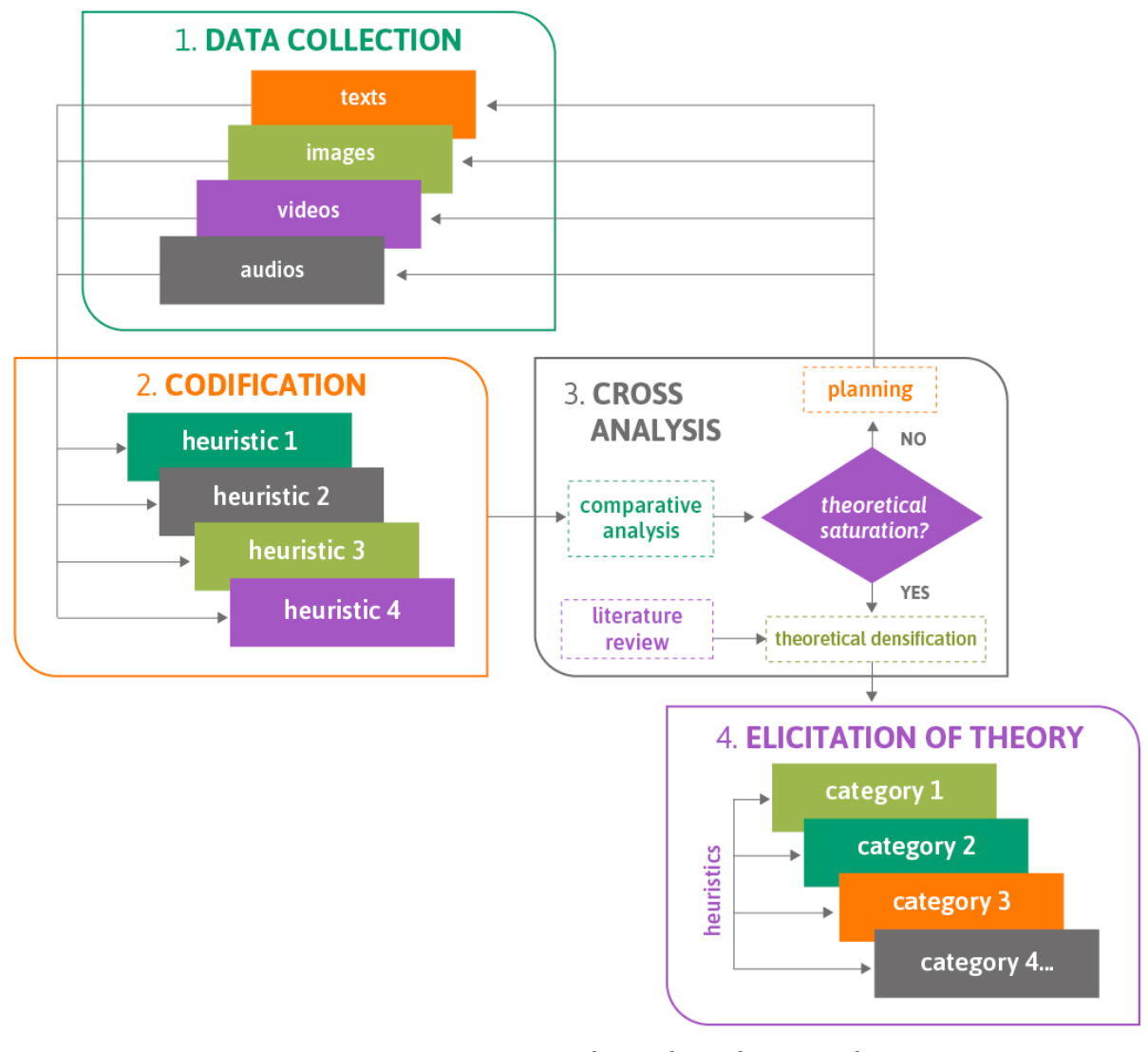

Source: Image taken by the authors

\subsection{Data Collection}

At this first stage, secondary data about the case to be analyzed is gathered. This collection is carried out on reports, videos, theses, dissertations and/or scientific articles, the case's websites and social media. From there, the sources are read to select the sections in which the heuristics of the case can be identified.

\subsection{Codification}

With the reading of the sources, the selected secondary data sections are then organized in a spreadsheet for codification. This organization 
allows data analysis to finally identify the heuristics of that section. An example of the result of this process is shown in chart 1 below:

Chart 1 - Structure for data codification

\begin{tabular}{|c|c|c|c|c|c|c|}
\hline Case & Short Code & $\begin{array}{c}\text { Source } \\
\text { Code }\end{array}$ & Source & $\begin{array}{c}\text { Secondary } \\
\text { data }\end{array}$ & Heuristic 1 & Heuristic 2 \\
\hline $\begin{array}{c}\text { 2- Bealieu } \\
\text { (Switzerland) }\end{array}$ & C2_01 & $\begin{array}{c}\text { caso02_ } \\
\text { Genebra } \\
\text { Suíça_ } \\
\text { Knapp, } \\
2013 \_ \\
\text {texto, } \\
\text { inglês_01 }\end{array}$ & $\begin{array}{c}\text { Wageningen } \\
\text { University } \\
\text { (KNAPP, 2013) }\end{array}$ & $\begin{array}{c}\text { "In the case of the Beaulieu } \\
\text { project, there are 3 } \\
\text { gardeners working part time } \\
\text { to cultivate the plants, and } \\
\text { the clients can come harvest } \\
\text { the products, while the } \\
\text { seedlings are sold to local } \\
\text { vegetable cooperatives." }\end{array}$ & $\begin{array}{c}\text { Show } \\
\text { freedom of } \\
\text { access to } \\
\text { the } \\
\text { surrounding } \\
\text { population } \\
\text { visits }\end{array}$ & $\begin{array}{c}\text { To integrate } \\
\text { commercial } \\
\text { distribution } \\
\text { channels of } \\
\text { production } \\
\text { results }\end{array}$ \\
& & & & & \\
\hline
\end{tabular}

Source: The Authors (2020)

\subsection{Cross Analysis}

After the individual analysis of each ex-post-facto case study, a cross analysis is then made with the heuristics identified in both cases. This is done for some purposes: (i) to check the saturation of the heuristics; (ii) in order to categorize heuristics into groups. This analysis is done in a cumulative manner (that is, additive assessments are made), highlighting the information that is confirmed between the cases for the categorization and hierarchization of the identified heuristics.

\subsection{Theory Elicitation}

Finally, there is a theoretical formulation on the identified heuristics, highlighting in which aspects there is a theoretical saturation. Here we seek to understand the possibility of formulating new constructs based on the analyzed data.

As a result, the tacit knowledge collected in these urban agriculture initiatives is sufficiently elicited in theory so that designers are more equipped with information when working specifically with services aimed at the practice of urban agriculture. With the theory elicitation, it is possible to indicate future work that can deepen and expand emerging knowledge.

\section{RESULTS AND DISCUSSION}

This section presents the results of this research, beginning with a brief description of the ex-post-facto case studies. Then, it shows the ten 
heuristics that were identified in them and their categorization. Finally, the Design meta-actions are derived from each heuristic. Firstly, in order to present the two cases analyzed, in chart 2 it is possible to see a brief description of each urban agriculture case. Next, in figures 4 and 5 there are some pictures of the environment of each one:

Chart 2 - Analysed cases

\begin{tabular}{|c|c|c|c|c|}
\hline Case & Location & Brief description & Since & References \\
\hline $\begin{array}{c}\text { 1. Uit Je Eigen } \\
\text { Ftad Urban } \\
\text { Farm }\end{array}$ & $\begin{array}{c}\text { Retterdam, } \\
\text { Netherlands }\end{array}$ & $\begin{array}{c}\text { Private initiative without } \\
\text { government support. The name } \\
\text { means "From your own city" and is } \\
\text { defined as an "experience farm". } \\
\text { They offer courses and workshops } \\
\text { to disseminate the practice of } \\
\text { urban agriculture. }\end{array}$ & $\begin{array}{c}\text { Elmqvist et al., 2018; } \\
\text { Kloot, 2015; Knapp, 2013; } \\
\text { Verstraeten, 2017. }\end{array}$ \\
\hline 2. Beaulieu \\
Urban Farm & $\begin{array}{c}\text { Geneva, } \\
\text { Switzerland } \\
\text { government support, originated } \\
\text { from civil society and several } \\
\text { collectives to occupy a public } \\
\text { space that was abandoned by the } \\
\text { government inside a park. }\end{array}$ & 2010 - today & $\begin{array}{c}\text { Knapp, 2013; Nikolaidou, } \\
\text { 2014; Pré en Bulle, 20-. }\end{array}$ \\
\hline
\end{tabular}

Source: The Authors (2020)

Figure 4 - Case 1: Uit Je Eigen Stad (Rotterdam, Netherlands)

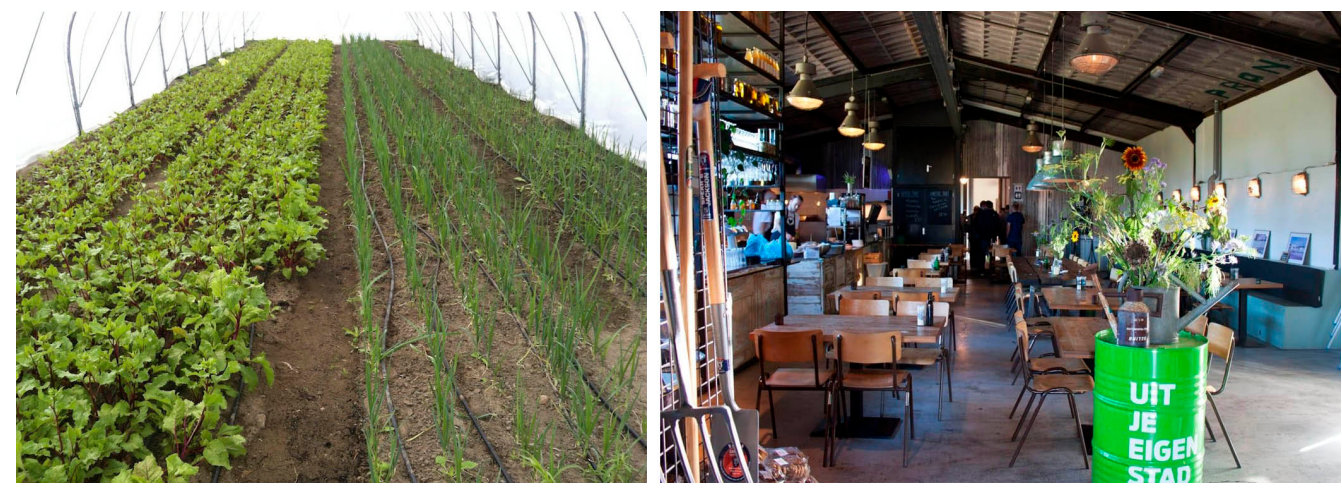

Source: Carstens, web, 2013; On the Grid, web, 201-; Kloot, 2015.

Figure 5 - Case 2: Beaulieu (Geneva, Switzerland)
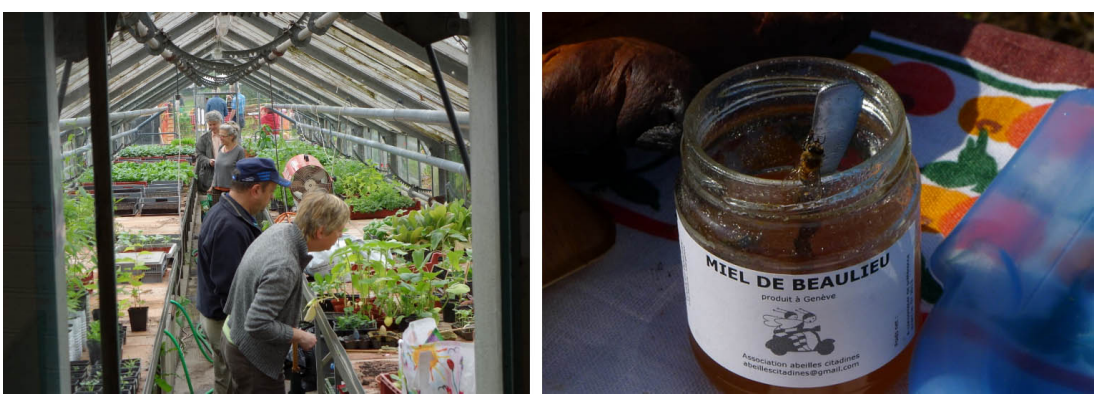

Source: Genève Cultive, web, 2018. 


\subsection{Identified heuristics, grouped by categories}

The ten heuristics identified in the two cases were organized into four categories, according to the area in which each heuristic has its greatest potential for impact. They are: (i) Education; (ii) Stakeholders; (iii) Receptiveness and (iv) Empowerment (chart 3). Each of the categories includes the following heuristics:

Chart 3 - Identified heuristics grouped by categories

\begin{tabular}{|c|c|c|}
\hline Category & Code & Heuristic title \\
\hline \multirow{2}{*}{ Education } & H01 & $\begin{array}{c}\text { To provide an experiential learning environment, aimed at instrumentalizing the } \\
\text { knowledge sharing with the community }\end{array}$ \\
\hline & $\mathrm{H} 02$ & $\begin{array}{l}\text { To increase awareness and involvement of the surrounding population through } \\
\text { learning activities }\end{array}$ \\
\hline \multirow{4}{*}{ Stakeholders } & $\mathrm{H} 04$ & $\begin{array}{l}\text { To integrate commercial distribution channels in order to contribute to the social } \\
\text { stability of the initiative through its economic viability }\end{array}$ \\
\hline & $\mathrm{H} 05$ & To allow the coexistence of different UA collectives in a shared space \\
\hline & H08 & $\begin{array}{l}\text { To demand public policies and resources for the development of the initiative aiming } \\
\text { the improving social cohesion }\end{array}$ \\
\hline & H010 & $\begin{array}{l}\text { To integrate the initiative with other urban agriculture groups and/or already existing } \\
\text { associations }\end{array}$ \\
\hline \multirow[b]{2}{*}{ Receptiveness } & H06 & To signal the freedom of access for visits by the surrounding population \\
\hline & $\mathrm{H} 07$ & To encourage social diversity among the participants \\
\hline \multirow{2}{*}{ Empowerment } & H09 & $\begin{array}{l}\text { To convert idle spaces into public spaces aimed at integrating urban agriculture with } \\
\text { cultural and educational activities }\end{array}$ \\
\hline & $\mathrm{H} 03$ & $\begin{array}{c}\text { To increase the adhesion of the surrounding community through co-creation } \\
\text { processes }\end{array}$ \\
\hline
\end{tabular}

Source: The Authors (2020)

\subsubsection{Education}

This group of heuristics corresponds to the scenarios evaluated in the cases in which the practices included the promotion of educational activities in the context of urban agriculture. Its purpose is not only concerned with technical issues associated with UA but includes, in an underlying way, the development of common views and strategies, whether for consumption and production patterns or for lifestyles and social values. 
This process of developing knowledge and values requires the preparation and availability of tools, techniques and physical space so that participants can learn about cultivation through action; and also by making classrooms available for workshops, promoting courses and cultivation workshops. In addition to the objective of replicating urban agriculture techniques, the aim of raising awareness among the community's population about the importance of the initiative is highlighted. In this sense, education needs to target not only active participants in the initiative, but the surrounding community, enhancing community involvement so that the actions promoted by such initiatives contribute to factors of community social cohesion.

\subsubsection{Stakeholders}

This category concerns social interactions and exchange relations with actors in the urban system, (e.g. government, commerce, restaurants, other agricultural groups), with direct participation or not in the initiative. The good relations of the initiative with the stakeholders can be the main factor that guarantees its establishment in the community. For example, the development of partnerships with distribution channels and logistics service providers contributes to the economic viability required for their livelihood.

A prominent stakeholder is the government. The nature of activities in an urban agriculture initiative, even though they can be operated independently of public resources, has wide-ranging repercussions that are of public interest. Achieving greater social cohesion is one of these objectives that, as a rule, should be part of the explicit or implicit agenda of government policies. Government support includes everything from the formulation of policies and regulations that enable the implantation of urban agriculture, to the provision of resources and infrastructure that enable its maintenance.

\subsubsection{Receptiveness}

This category groups the heuristics that seek to promote welcoming or a good receptivity for people in contact with the initiative, whether they are active participants in daily life or sporadic visitors. A friendly presentation of the initiative is essential for its internal cohesion and also for attracting 
visitors and potential consumers.

As in the cities the meaning of "agriculture" is often dissociated from the urban context itself, the action of welcoming has the role of reducing this estrangement. Just as it would happen in technological hubs installed in rural areas, the approximation of agriculture activity in the urban space demands the contribution of Design in changing the meanings associated with the activity. From a "dirty", "heavy", "minor", "prosaic" activity, the challenge is to place it in the status of a modern, relaxing, healthy habit, which leads to understanding, respecting differences and getting closer to other people working together in that activity.

\subsubsection{Empowerment}

This category includes the heuristics that aim to expand the protagonism and the power of participation. According to the identified heuristics, this empowerment can emanate from people in the surrounding community to participate in creative decision-making through the application of co-creation processes (e.g. workshops for cocreation of the service, complete redesign of the type of service offered, wayfinding and signaling).

Another relevant proposition for empowerment is the resumption of city spaces that are not exercising their social function for the common good. In this way, the consolidation of the presence of these initiatives reinforces the status of the community as the protagonist of its region, as it proposes to redefine uses and build new relationships with the city space (NAGIB, 2016). This occupation of idle spaces expresses that people and communities can be empowered "to create new common spaces for socialization and political action" (HARVEY, 2014, p. 22).

\subsection{Implications of Heuristics for Design}

Since the main objective of the heuristic method is precisely to transform tacit knowledge into explicit information - often in the form of good practices or guidelines - that can be communicated and used by more people (SANTOS et al., 2018), a summary table (table 4) of heuristics was developed with meta-actions for the designer in urban agriculture projects.

These meta-actions are presented as practical deployments for each 
of the ten identified heuristics. They emerged from the experience framework of the researcher with Service Design and Design for Social Innovation as a way of activating, sustaining and guiding urban agriculture initiatives and diverse social innovations (with other specialties) that have similar operating characteristics:

\section{Chart 4 - Design meta-actions}

\begin{tabular}{|c|c|}
\hline $\begin{array}{c}\text { Category, code } \\
\text { and title }\end{array}$ & Design meta-actions - Suggestions for the designer \\
\hline $\begin{array}{l}\text { [Education] } \\
\text { H01. To provide an } \\
\text { experiential learning } \\
\text { environment aimed at } \\
\text { instrumentalizing } \\
\text { knowledge sharing with } \\
\text { the community }\end{array}$ & $\begin{array}{l}\text { 1.1) To promote the integration of community actors and agricultural experts to } \\
\text { design the space jointly; } \\
\text { 1.2) To design the space of the rooms; } \\
\text { 1.3) To signal the availability of personal hygiene materials and personal protective } \\
\text { equipment (PPE); } \\
\text { 1.4) To design furniture with reuse of available materials in the area; } \\
\text { 1.5) To make identification plates for the cultivated species; } \\
\text { 1.6) To produce plates with information about cultivation; } \\
\text { 1.7) To help choose colors and painting indoor and outdoor areas; } \\
\text { 1.8) To make Illustrations on walls at and near the initiative (e.g. graffitti, murals); } \\
\text { 1.9) To run workshops to co-create with other participants the contact points and } \\
\text { guided tours for the community, groups and/or schools; } \\
\text { 1.10) To integrate and train the community actors so that they can guide the visiting } \\
\text { process; } \\
\text { 1.11) To concept and provide a cultivation space for experiments in which the } \\
\text { demands come from the community; }\end{array}$ \\
\hline $\begin{array}{l}\text { [Education] } \\
\text { H02. To increase } \\
\text { awareness and } \\
\text { involvement of the } \\
\text { surrounding population } \\
\text { through learning activities }\end{array}$ & $\begin{array}{l}\text { 2.1) To help create workshops to share knowledge about cultivation; } \\
\text { 2.2) To be involved in visits to close communities with informative materials and } \\
\text { dissemination of activities; } \\
\text { - Materials to enable educational activities: } \\
\text { 2.3) To prepare presentations for courses, lectures and workshops; } \\
\text { 2.4) To prepare attractive flipcharts to support courses when there is no digital } \\
\text { infrastructure; } \\
\text { 2.5) To layout supporting materials (e.g. booklets with cultivation tutorials); } \\
\text { 2.6) To design online and offline advertising materials for the activities; } \\
\text { 2.7) To help plan the experience of guided and explanatory visits for the community, } \\
\text { groups and/or schools; } \\
\text { 2.8) To design basic cultivation toolkits for participants; }\end{array}$ \\
\hline $\begin{array}{l}\text { [Stakeholders] } \\
\text { H04. To integrate } \\
\text { commercial distribution } \\
\text { channels in order to } \\
\text { contribute to the social } \\
\text { stability of the initiative } \\
\text { through its economic } \\
\text { viability }\end{array}$ & $\begin{array}{l}\text { 4.1) To design sales service "from garden to table"; } \\
\text { 4.2) To design a service where users collect and weigh their own food; } \\
\text { 4.3) To include in the system map exchanges with restaurants, greengrocers and } \\
\text { other nearby establishments; } \\
\text { 4.4) To support the opening of attached trade activities, such as restaurants and } \\
\text { greengrocers linked to production; } \\
\text { 4.5) To help promoting fairs or planning to participate in third-party fairs, drawing } \\
\text { points of contact with the final consumer, such as: visual identity and } \\
\text { communication material for the fair, vendor uniforms, price signs and product } \\
\text { labels; }\end{array}$ \\
\hline $\begin{array}{l}\text { [Stakeholders] } \\
\text { H05. To allow the } \\
\text { coexistence of different } \\
\text { collectives in a shared } \\
\text { space }\end{array}$ & $\begin{array}{l}\text { 5.1) To promote a coworking system, defining the satisfaction unit for the groups } \\
\text { involved and the blueprint of the land sharing service; } \\
\text { 5.2) To integrate community actors and specialists in agriculture to project the space } \\
\text { jointly, helping organize the shared space with design artifacts; } \\
\text { 5.3) To design the layout in order to group the types of cultivation that complement } \\
\text { each other; } \\
\text { 5.4) To plan moments, or even workshops, of integration and sharing of experiences; }\end{array}$ \\
\hline
\end{tabular}




\begin{tabular}{|c|c|}
\hline $\begin{array}{c}\text { Category, code } \\
\text { and title }\end{array}$ & Design meta-actions - Suggestions for the designer \\
\hline $\begin{array}{l}\text { [Stakeholders] } \\
\text { H08. To demand public } \\
\text { policies and resources for } \\
\text { the development of the } \\
\text { initiative aimed at } \\
\text { improving social cohesion }\end{array}$ & $\begin{array}{l}\text { 8.1) To prepare online and offline campaign materials for mobilization; } \\
\text { 8.2) To participate in the design of public policies to support urban agriculture; } \\
\text { 8.3) To prepare presentations, videos and animations to argue demands in meetings } \\
\text { with members of the government; } \\
\text { 8.4) To help to show visually the data about the results and benefits of the urban } \\
\text { agriculture project for communities; } \\
\text { 8.5) To create a model that can be replicated in government campaigns (social } \\
\text { franchises); }\end{array}$ \\
\hline $\begin{array}{l}\text { [Stakeholders] } \\
\text { H10. To integrate the } \\
\text { initiative with other urban } \\
\text { agriculture groups and/or } \\
\text { already existing } \\
\text { associations }\end{array}$ & $\begin{array}{l}\text { 10.1) To plan a service for changing seedlings; } \\
\text { 10.2) To elaborate the initiative's visual identity for a good presentation to other } \\
\text { groups; } \\
\text { 10.3) To design and visual identity of the urban farmers association; } \\
\text { 10.4) To produce images and videos for association posts on social networks; }\end{array}$ \\
\hline $\begin{array}{l}\text { [Receptivity] } \\
\text { H06. To signal freedom of } \\
\text { access } \\
\text { for visits by the } \\
\text { surrounding population }\end{array}$ & $\begin{array}{l}\text { 6.1) To signal the areas where visitors are welcome and "staff only" areas; } \\
\text { 6.2) To integrate and train community actors so that they can guide the visiting } \\
\text { process; } \\
\text { 6.3) To help plan the experience of guided and explanatory visits for the community, } \\
\text { groups and schools; } \\
\text { 6.4) To plan trips to meet close communities to publicize activities; } \\
\text { 6.5) To design materials for divulgation (online and offline) of fairs in the cultivation } \\
\text { space; }\end{array}$ \\
\hline $\begin{array}{l}\text { [Receptivity] } \\
\text { H07. To encourage social } \\
\text { diversity among initiative } \\
\text { participants }\end{array}$ & $\begin{array}{l}\text { 7.1) To design the selection process for participants, criteria and phases of the } \\
\text { selection; } \\
\text { 7.2) To prepare a registration form for people interested in participating in the } \\
\text { initiative; } \\
\text { 7.3) To facilitate empathy workshops to sensitize participants from different social } \\
\text { realities; }\end{array}$ \\
\hline $\begin{array}{l}\text { Empowerment] } \\
\text { H09. To convert idle } \\
\text { spaces into public spaces } \\
\text { aimed at integrating urban } \\
\text { agriculture with cultural } \\
\text { and educational activities }\end{array}$ & $\begin{array}{l}\text { 9.1) To map potential spaces (with public agencies or private properties) for the } \\
\text { implementation of collective urban gardens; } \\
\text { 9.2) To integrate community actors and specialists in agriculture to design the space } \\
\text { jointly, helping organize the shared space with design artifacts; } \\
\text { 9.3) To help organize the division of the land chosen for cultivation by species with } \\
\text { design artifacts; } \\
\text { 9.4) To elaborate a map of the cultivated species; } \\
\text { 9.5) To design the structures where the cultivation will take place (e.g. boxes, } \\
\text { greenhouses, corrals, fences, etc.) } \\
\text { 9.6) To produce images and videos for recording occupation activities and } \\
\text { dissemination on social media; }\end{array}$ \\
\hline $\begin{array}{l}\text { [Empowerment] } \\
\text { H03 - To increase the } \\
\text { adhesion of the } \\
\text { surrounding community } \\
\text { through co-creation } \\
\text { processes }\end{array}$ & $\begin{array}{l}\text { 3.1) To integrate community actors and specialists in agriculture to design the space } \\
\text { jointly, helping organize the shared space with design artifacts; } \\
\text { 3.2) To design interactions with the community that make sense to everyone (e.g. } \\
\text { space for exchanging recipes, harvest day, exchanging seeds and seedlings, } \\
\text { shared meals); } \\
\text { 3.3) To propose service co-creation sessions (e.g. complete redesign of the type of } \\
\text { service offered, signage and wayfinding, preliminary decisions regarding the } \\
\text { implantation of the cultivation space); } \\
\text { 3.4) To plan visits to close communities to raise their demands regarding jobs, food, } \\
\text { community health, and integrate them in creating solutions to these demands; } \\
\text { 3.5) To integrate and train community actors so that they can guide the visiting } \\
\text { process. }\end{array}$ \\
\hline
\end{tabular}

Source: The Authors (2020) 
It is important to highlight that these suggestions in no way exhaust the designer's alternatives for action on behalf of social cohesion in urban agriculture. On the contrary, it is hoped that the summary table will serve as a recommendation and stimulus for new ideas, so that the opportunities to place Design at the service of urban agriculture can be expanded.

\section{CONCLUSION}

This article explores the role of urban agriculture initiatives in maintaining and increasing social cohesion. It is positioned at the intersection of Design for Social Innovation and Service Design. The agency of Urban Agriculture in order to build greater social cohesion was investigated from the analysis of experiences in two ex-post-facto case studies. This analysis resulted in the identification of ten heuristics and 56 meta-actions, which can be applied by designers involved in Service Design, Social Innovation initiatives, and other Design projects regarding social cohesion matters. Note that, although the emphasis on the research is given to urban agriculture initiatives, the study is also relevant to other initiatives of a similar nature, where creative communities are involved in the implementation of collaborative projects.

The identified heuristics recommend what can be done, constituting a mechanism that can contribute accelerating the creative process, bypassing the learning curve that is often necessary when working with wicked problems ${ }^{3}$, such as the search for social cohesion via urban agriculture initiatives. For these heuristics and meta-actions to become an effective transformation in the real world, they can be integrated into criteria, tools, methods and methodologies, contributing to greater effectiveness in the process of developing and implementing solutions.

The approach of resorting to the ex-post-facto case studies - using published information about them and using grounded theory as an

3 - These are problems that are difficult to define: their scope is incomplete, they have mobile requirements, multiple interdependencies that make it difficult to recognize solutions, they do not have right or wrong answers (but better or worse ones), whereas the nature of the problem changes over time and it is difficult to guarantee that it has been solved, as there is no predetermined end (RITTEL \& WEBBER, 1973), or there is an abstract concept as ideal goal. 
analysis strategy - made it possible to achieve the objectives set for the research. In fact, it is highlighted that in atypical situations, such as the one experienced during this research with the occurrence of a pandemic (COVID-19), the use of ex-post-facto case studies has the benefit of allowing the research to be carried out, even if remotely.

However, it is considered that the possibility of direct contact with the case studies would increase the degree of internal and external validity. In fact, the use of secondary data and information available online (reports, theses, news articles, websites, social media, etc.) implies noise in the interpretation of reality. Failure reports are less presented in these publications: good practices, positive points and reasons for success are usually highlighted. Therefore, it is recommended for future studies to consider a complementary step to an ex-post-facto case study that allows assessing the internal validity of the facts through direct contact with the initiative. Note that specific tools, methods and strategies of Service Design and Design for Social Innovation were not identified in the secondary data analyzed. In the case of the possibility of collecting primary data (directly collected by the researcher), the reasons for this situation could be investigated in depth.

It is noteworthy that the presented heuristics and meta-actions do not cover the whole and do not exhaust the alternatives of the designer's performance in favor of social cohesion in urban agriculture. On the contrary, the results presented are expected to serve as a recommendation and stimulus for new heuristics, so that the opportunities to put Service Design and Design for Social Innovation at the service of urban agriculture can be expanded.

The application of the heuristic method made it possible to point out specificities of the research object analyzed (cases of urban agriculture), through the identification of the presented heuristics. Among them, there are the following findings: (i) achieving the economic viability is fundamental for maintaining social cohesion in the long term; (ii) sharing of knowledge about cultivation is an important part of the initiatives, being another means of stimulating social cohesion; and the need for (iii) direct action to occupy, revitalize and redefine spaces for cultivation in the cities.

In order to optimize the degree of external validity of the identified heuristics, it is necessary to expand the number of cases studied. As the research time period only allowed the investigation of two cases, it is 
believed that the confirmation of the identified heuristics is still in its initial phase. There are numerous recent cases that can be explored to improve these results. The analysis of a larger number of cases may make it possible to increase the number of heuristics and refine those already defined.

The context of the conclusion of the present research in the midst of the COVID-19 pandemic also imposes the suggestion to investigate strategies for social cohesion in contexts of catastrophes and crises. With the pandemic, the need for physical isolation was demanded, which paradoxically results in the search for social cohesion through remote strategies. In this sense, the study of solutions that allow the implementation of urban agriculture initiatives and, at the same time, guarantee the health of the people involved, is a topic that is relevant today.

Since the factors of the social dimension of sustainability are considered difficult to define, quantify and implement (KJøLLESDAL, ASHEIM \& BOKS, 2014), it is important to create indicators that allow their integration in the Design process. These indicators can help to clarify the frequency of social interactions, the state of the sense of belonging to the community, the level of freedom of expression and the depth of respect for diversity, for example. The definition of these parameters and indicators is complementary to the identification of heuristics, whose relevance can be validated through the evaluation of these indicators.

With a group of heuristics identified and sufficiently confirmed, it will be possible and necessary to develop tools for Service Design and Design for Social Innovation based on them. The tools can be applicable when creating, implementing or iterating service improvements, for example. Finally, it is suggested carrying out another external validation of the listed heuristics through action research with designers in urban agriculture initiatives. The day-to-day experience of cultivation and the relationship between the people involved, together with the proposition of collective Design activities by the designer will certainly provide new perspectives for the heuristics already identified and for those yet to come.

\section{REFERENCES}

CARSTENS, K. Uit Je Eigen Stad City Farm - From Your Own Town. 28 mai. 2013. Susdane. Disponível em: <http://susdane.com/food/2013/5/28/uit-jeeigen-stad-city-farm-from-your-own-town>. Acesso em: 29 out. 2019.

CHARMAZ, K. A Construção da Teoria Fundamentada: Guia prático para 
análise qualitativa. Artmed, Porto Alegre, 2009.

CHAVES, A. et al. Design para a sustentabilidade: Dimensão Social. Curitiba, PR: Insight, 2019.

CIPOLLA, C. et al. Service Design for Social Innovation: the Promotion of Active Aging in Rio De Janeiro. In: Service Design Geographies. Proceedings of the ServDes. 2016 Conference. Linköping University Electronic Press, 2016. p. 365375.

ELMQVIST, Thomas (Ed.). The Urban Planet: Knowledge Towards Sustainable Cities. Cambridge University Press, 2018.

FENIMAN, Eduardo Henrique. Hortas curitibanas: as representações simbólicas do cultivo de alimentos na cidade. 2014. Dissertação de Mestrado. Universidade Federal do Paraná.

Food and Agriculture Organization of the United Nations (FAO). Urban Agriculture. Disponível em: <http://www.fao.org/urban-agriculture/en/> Acesso em:Junho 2019.

GENÈVE CULTIVE. Map. Ferme urbaine. 2018. Disponível em: <http://www.genevecultive.ch/map>. Acesso em: 31 out. 2019

HARVEY, D. Cidades rebeldes: do direito à cidade à revolução urbana. São Paulo: Martins Fontes, 2014.

KARUPPANNAN, Sadasivam; SIVAM, Alpana. Social sustainability and neighborhood design: an investigation of residents' satisfaction in Delhi. Local Environment, v. 16, n. 9, p. 849-870, 2011.

KJØLLESDAL, Anders; ASHEIM, Jonas; BOKS, Casper. Embracing Social Sustainability in Design Education: A Reflection on a Case Study in Haiti. Scandinavian Journal of Educational Research, v. 58, n. 2, p. 173-188, 2014.

KLOOT, W. How a Rotterdam Squat Became a Cutting-Edge Farm. Vice Magazine. 20 fev. 2015. Disponível em:

<https://www.vice.com/en_us/article/8qkjqg/how-a-rotterdam-squat-becamea-cutting-edge-farm>. Acesso em: 29 out. 2019.

KNAPP, Ladina. Implementing urban agriculture in Europe: A case study of urban agriculture projects in the Netherlands and Switzerland. Tesis tidak diterbitkan. Wageningen: Wageningen University and Research Centre. 2013.

LEHMANN, H. A Grounded Theory of International Information Systems. Doctor of Philosophy Thesis, The University of Auckland, 2001.

MANZINI, E. Design quando todos fazem design: uma introdução ao design para inovação social. Tradução Luzia Araujo. São Leopoldo, RS: Ed. Unisinos, 2017.

MORAES, Antonio Carlos Robert. Ideologias geográficas. São Paulo: Annablume, 2005.

MORITZ, S. Service design: practical access to an evolving field. Köln 
International School of Design, 2005.

MOUGEOT, L. J.A. Agricultura Urbana - conceito e definição. Revista Agricultura Urbana n01. Julho de 2000. Disponível em:

<http://www.agriculturaurbana.org.br/RAU/AUrevista.html>. Acesso em abril 2019.

NAGIB, Gustavo. Agricultura urbana como ativismo na cidade de São Paulo: o caso da Horta das Corujas. 2016. Tese de Doutorado. Universidade de São Paulo.

NIKOLAIDOU, Sofia. Emerging forms of Urban Gardening in Geneva. Urban Allotment Gardens in European Cities Future, Challenges and Lessons Learned. Short Term Scientific Mission Report. 2014.

ON THE GRID. Uit Je Eigen Stad. 201-. Disponível em:

$<$ https://onthegrid.city/rotterdam/west/uit-je-eigen-stad>. Acesso em: 29 out. 2019.

PrÉ EN BULLE. Beaulieu. Disponível em:

$<$ https://www.preenbulle.ch/113/Beaulieu> Acesso em: 16 out. 2019.

RUAF. Resource Centres on Urban Agriculture \& Food Security Foundation. Urban Agriculture and City Region Food Systems: What and Why. 2015. Disponível em: <https://ruaf.org/urban-agriculture-and-city-region-foodsystems/\#urban-and-peri-urban-agriculture>. Acesso em: 04 de mai. de 2020.

REYNOLDS, R. On guerrilla gardening: a handbook for gardening without boundaries. Reino Unido: Bloomsbury, 2009.

SANTOS, Aguinaldo dos (org). Seleção do Método de Pesquisa: guia para pósgraduandos em Design eáreas afins. Editora Insight, 2018.

TRACEY, D. Guerrilla gardening: a manualfesto. Canadá: New Society, 2007.

VEENHUIZEN, R. VAN (Ed.). Cities farming for the future: urban agriculture for green and productive cities. Holanda: RUAF \& IDRC, 2006.

VERSTRAETEN, René. UitJe Eigen Stad ENGLISH. Alessandro Rossi/MAMMUT FILM. 22 mar. 2017. Disponível em:

<https://www.youtube.com/watch?v=QQ_c7v-wVxl>. Acesso em: 20 out. 2019. 


\section{Mariana Schmitz Gonçalves}

She holds a Master's in Design from the Federal University of Paraná and is a professor of Design at the UNINTER International University Center. Graduated in Design with emphasis in Visual Programming at the University of the Region of Joinville - UNIVILLE with an exchange of two semesters in the Communication Design course at the Faculty of Fine Arts of the University of Porto (Portugal). She is mainly interested in the themes: Design for Sustainability, Design for Social Innovation, and Codesign.

\section{Aguinaldo dos Santos}

He is a professor of the Product Design Course and of the Postgraduate Program in Design at UFPR, and coordinator of the Design \& Sustainability Center. He has a technical course in Automotive Mechanics (SENAl, 1984), degree in Civil Engineering (1992), Master in Civil Engineering (UFRGS, 1995), PhD in Operations Management (SALFORD, 1999), and did his postdoctoral in Design for Sustainability (POLIMI, 2009). His research focus is Design for Sustainability, with the main research object being Social Interest Housing. 